\title{
The effect of degumming by hydration on the purification of high acidity solvent extracted olive oil
}

\author{
By C.D. Thomopoulos and C. Tzía * \\ Department of Chemical Engineering. Laboratory of Food Technology. \\ National Technical University of Athens. Zografou, 15780, Athens, Greece.
}

\section{RESUMEN}

Efecto del desgomado por hidratación sobre la depuración de los aceites de orujo de alta acidez.

El resultado del desgomado, controlado por la disminución del contenido en fósforo, fue estudiado según los siguientes factores: temperatura de hidratación, porcentaje de agua en el aceite y tiempo de contacto a la temperatura de hidratación. La hidratación a $95^{\circ} \mathrm{C}$ con $2 \%$ de agua y tiempo de contacto de 15 minutos, dio la máxima eliminación del contenido en fósforo del aceite crudo y el mínimo de pérdidas en aceite. Cambiando la temperatura de 95 a $80^{\circ} \mathrm{C}$ y manteniendo el contenido en agua al $2 \%$ y el tiempo de contacto de 15 minutos, aumentó la pérdida de aceite en un $2.19 \%$. Bajo estas condiciones, y en ambos casos, se consiguió eliminar el $35-48 \%$ del contenido en fósforo del aceite crudo, eliminándose el residual mediante la neutralización alcalina.

PALABRAS-CLAVE: Aceite de orujo - Desgomado - Fósforo - Hidratación.

\section{SUMMARY}

The effect of degumming by hydration on the purification of high acidity solvent extracted olive oil.

The degumming result of the following factors was studied: the temperature of hydration, the percentage of water in oil and the contact time at the hydration temperature. The hydration at $95^{\circ} \mathrm{C}$ with $2 \%$ water for a contact time of 15 min resulted in maximum removal of phosphorus of the oil with minimum oil losses. The same purification result was also attained at $80^{\circ} \mathrm{C}$ with $2 \%$ water and for a contact time of 15 min causing $2.19 \%$ greater losses of the oil. Under these conditions the hydration resulted in an about $35-48 \%$ removal of the phosphorus in crude oil. The residual phosphorus was removed by subsequent alkali neutralization.

KEY-WORDS: Degumming - Foot cake oil - Hydration - Phosphorus.

\section{INTRODUCTION}

Most solvent extracted oils contain considerable amounts of phosphatides, metal complexes and other mucilagineous material which must be removed from the oil by the degumming process. The presence of phosphatides increases the risk of losses due to the formation of emulsions during the alkali treatment and a disagreeable flavor may occur after deodorization (1). The degumming is carried out immediately before neutralization or concurrently with it (2).
Various methods for degumming of oils have been suggested:

a) Treatment with inorganic acid (e.g. $\mathrm{H}_{3} \mathrm{PO}_{4}, \mathrm{HCl}$, $\mathrm{H}_{2} \mathrm{SO}_{4}, \mathrm{HNO}_{3}, \mathrm{HBO}_{3}$, etc.) (2) (3) (4) (5); two main processes are in use: dry and wet degumming (6).

b) Treatment with organic acid or acid anhydride (e.g. acetic, citric, oxalic acid, maleic anhydride, etc.) (4) (5) (7).

c) Water degumming (hydration).

Water degumming is especially applicable to crude oils with high content of phosphatides, in which case lecithins can be obtained (1) (2).

Crude vegetable oils contain different types of phospholipids: phosphatidyl choline (PC), phosphatidyl inositol (PI), phosphatidyl ethanolamine (PE), which are hydratable and phosphatidic acid (PA) and phytospingolipids which are nonhydratable (8). PA and PE are present as $\mathrm{Ca}$ and/or $\mathrm{Mg}$ salts (9).

Degumming exploits the affinity of phosphatides for water by converting them to hydrated gums. Hydration occurs with the ionic part of phospholipid molecule (10). The hydrated gums are insoluble in oil and permit their removal by centrifugation (11) (12). The rate of hydration varies substantially for the different phosphatides, so that $\mathrm{PC}$ and $\mathrm{PI}$ are fast hydratable, and PA and PE are slower hydratable (9). The position of $\mathrm{H}_{3} \mathrm{PO}_{4}$ in the phosphatidic molecule is also important for hydration. $\alpha$-Lipoids are hydratable and may be removed by water degumming. $\beta$ Lipoids, which are not hydratable, remain in the oil and they are removed during the alkali refining (12) (13) (14). Metal complexes are precipitable as insoluble phosphates by phosphoric acid treatment (14). Nonhydratable phosphatides may originate during the extraction because of an enzymatic reaction due to the presence of moisture. The Alcon process aims to the deactivation of this enzyme by a treatment which prevents the formation of nonhydratable phospholipids (9) (11). According to this process, it is claimed that the phosphatides can be removed by water degumming to a low residual content, below $0.1 \%(11)$.

In water degumming the amount of water, the temperature of hydration and the contact time are of great significance for hydration of phosphatides (15). Usually, water is $2-5 \%$ to oil and the contact time with the oil at the tempera- 
ture of hydration is $10-30 \mathrm{~min}(1)$ (13). The temperature of hydration is $60-70^{\circ} \mathrm{C}$ (11) (13), when lecithin production from the byproducts is desired. Since the purpose of hydration is the degumming, a higher temperature is used, namely $80-90^{\circ} \mathrm{C}(3)(13)$.

The purpose of this research was to study the water degumming of solvent extracted olive oil under different conditions of hydration and to examine the quality of the obtained degummed oils.

\section{EXPERIMENTAL}

\subsection{Materials}

The crude solvent extracted olive oil with the following characteristics was used:

Free Fatty Acid (expressed as oleic acid): $25.51 \%$. Phosphorus: 220 ppm (phosphatides: 0.613\%). Unsaponifiable Matter: $3.53 \%$. lodine Value: 73.5.

\subsection{Experimental Technique}

$500 \mathrm{~g}$ of crude solvent extracted olive oil were heated to the hydration temperature. Hot water was added dropwise to the oil under stirring $(750 \mathrm{rpm})$. When the addition of the water was completed, the agitation was reduced (500 rpm) and the mixture was stirred at the same temperature for a time equal to the contact time. The oil was then allowed to settle and the hydrated phosphatides were separated by centrifugation (3500 rpm). The hydrated gums were dried at $70^{\circ} \mathrm{C}$ for $24 \mathrm{~h}$ to remove the water and then extracted with petroleum ether to remove the oil held. Experiments of degumming by hydration were conducted at $80^{\circ} \mathrm{C}$ and $95^{\circ} \mathrm{C}$, at a percent of water to oil $2 \%$ and $5 \%(\mathrm{w} / \mathrm{w})$ and for a contact time of $10 \mathrm{~min}$ and $15 \mathrm{~min}$.

A larger scale experiment $(4.5 \mathrm{~kg})$ under the best conditions of degumming was conducted using the same procedure. Followingly the degummed oil was splitted into samples of $500 \mathrm{~g}$ which were neutralized at $60^{\circ} \mathrm{C}$ with $10^{\circ} \mathrm{Be}$ $\mathrm{NaOH}$ or at $70^{\circ} \mathrm{C}$ with $20^{\circ} \mathrm{Be} \mathrm{NaOH}$. NaOH solution containing $10 \% \mathrm{NaCl}$ was used in $10 \%$ excess. After settling, the soapstock was separated by centrifugation (3500 rpm) and the oil was washed with hot water and dried. The degummed and the neutralized oil were examined for their quality characteristics. Each experiment was duplicated and the average of the results is presented.

\subsection{Analytical methods}

a) Free fatty acids (\%) were determined by the IUPAC method and are expressed as oleic acid (16).

b) Phosphorus content was determined colorimetrically by the phosphovanadomolybdate method. The equivalent phosphatide content of the oil was calculated by multiplying the percentage of phosphorus by 27.86 (17). c) The unsaponifiable matter was determined according to the official AOCS method Ca $6 a-40$ (18).

\section{RESULTS AND DISCUSSION}

The crude solvent extracted olive oil had a content of $220 \mathrm{ppm}$ phosphorus. The results of the degumming experiments under different conditions of hydration are presented in Table I. The method of water degumming caused a $35-48 \%$ decrease of phosphorus of the crude oil depending on the conditions of hydration. As shown in Table I the degumming result was influenced mainly by the contact time of hydration and less by the temperature or the amount of water of hydration. The degumming result was improved with longer contact time (15 min). The degumming for a 20 min contact time was examined, but it did not contribute to a significantly improved purification of the oil.

Table I

Degumming result of degumming by hydration

\begin{tabular}{|c|c|c|c|c|c|c|c|c|}
\hline $\begin{array}{l}\text { Number of } \\
\text { experiment }\end{array}$ & 1 & 2 & 3 & 4 & 5 & 6 & 7 & 8 \\
\hline Temperature $\left({ }^{\circ} \mathrm{C}\right)$ & 80 & 80 & 95 & 95 & 80 & 80 & 95 & 95 \\
\hline Water \% to oil & 2 & 5 & 2 & 5 & 2 & 5 & 2 & 5 \\
\hline $\begin{array}{l}\text { Contact time (min) } \\
\text { ppm P }\end{array}$ & 10 & 10 & 10 & 10 & 15 & 15 & 15 & 15 \\
\hline $\begin{array}{l}\text { of degummed oil } \\
\% \text { Removal }\end{array}$ & 143 & 144 & 136 & 131 & 115 & 117 & 115 & 115 \\
\hline of phosphorus & 35.0 & 34.5 & 38.2 & 40.5 & 47.7 & 46.8 & 47.7 & 47.7 \\
\hline
\end{tabular}

It is known that degumming by hydration causes a less satisfactory removal of phosphatides with respect to the removal attained when acids are used as degumming agents (5) (7). The water degumming can attain a $80-95 \%$ removal of the phosphatides that are present in the crude oil (2) (13). In our experiments, the obtained removal of phosphorus was not very high. Phosphatide purification efficiency is depended however on the oil, so that the removal of phosphorus ranges from 40 to $60 \%$ (5) (7). In solvent extracted olive oil this may be attributed to the large amounts of nonhydratable phosphatides present. To our knowledge the literature on the identification of the olive kernel oil phosphatides is limited. Among the phosphatides that have been identified in olive kernel are phosphatidyl choline and ethanolamine, both of which have oleic acid as a main fatty acid (19).

The analysis of the separated gums is shown in Table II. They contained water, phosphatides insoluble in petroleum ether and some amount of oil. From the results it is obvious that the degumming result was better when the amount of the separated gums (dry basis) was higher. Also, in these cases, the amount of oil that the gums contained was smaller.

Comparing the degumming result (Table I) with the losses of the oil held in the gums (Table II) it can be seen that under the hydration conditions of $95^{\circ} \mathrm{C}$ with $2 \%$ water the maximum removal of phosphorus with the minimum 
losses of the oil was obtained. However, degumming at $80^{\circ} \mathrm{C}$ with $2 \%$ water had an equivalent result in oil purification with $2,19 \%$ higher oil losses than that at $95^{\circ} \mathrm{C}$ with $2 \%$ water. Thus, the second conditions should be preferred since the same result is obtained under milder conditions.

Table II

Analysis of separated gums (\% crude oil)

\begin{tabular}{lcccccccc}
\hline $\begin{array}{l}\text { Number of } \\
\text { experiment }\end{array}$ & 1 & 2 & 3 & 4 & 5 & 6 & 7 & 8 \\
\hline Wet gums & 15.26 & 20.58 & 17.16 & 22.52 & 22.51 & 24.67 & 20.48 & 24.31 \\
$\begin{array}{l}\text { Dried gums } \\
\text { Insoluble in }\end{array}$ & 14.49 & 19.50 & 16.54 & 21.17 & 21.86 & 23.91 & 19.67 & 23.43 \\
petroleum ether & 8.99 & 12.10 & 9.49 & 15.64 & 16.66 & 18.96 & 14.92 & 18.90 \\
Matter oil in gums & 5.50 & 7.40 & 7.05 & 5.53 & 5.20 & 4.95 & 4.75 & 4.53 \\
\hline
\end{tabular}

In addition to the decrease of the phosphatides content of the degummed oil the other quality characteristics which are significant for the oil, are presented in Table III. In all the examined conditions of hydration an increase of the acidity of the degummed oil was observed. This increase can be attributed to the increase of the fatty acids concentration in the degummed oil after the removal of the gums or to the partial hydrolysis of the triglyceridic molecules. The increase of the acidity was higher for the longer contact time of hydration. From the other features of the degummed oils, the unsaponifiable matter (\%) decreased during the hydration, but did not vary significantly with the conditions of degumming. The lodine Value of the degummed oil increased after the hydration and did not vary much with the conditions of degumming.

Table III

Features of degummed oils

\begin{tabular}{lcccccccc}
\hline $\begin{array}{l}\text { Number of } \\
\text { experiment }\end{array}$ & 1 & 2 & 3 & 4 & 5 & 6 & 7 & 8 \\
\hline $\begin{array}{l}\text { \% Phosphatides } \\
\begin{array}{l}\text { Free fatty } \\
\text { acids \% }\end{array}\end{array}$ & 0.399 & 0.400 & 0.378 & 0.365 & 0.321 & 0.325 & 0.319 & 0.321 \\
$\begin{array}{l}\text { Unsaponifiable } \\
\text { matter \% }\end{array}$ & 27.58 & 27.57 & 27.64 & 27.50 & 29.22 & 29.40 & 29.26 & 29.26 \\
lodine value & 2.90 & 2.81 & 2.83 & 2.76 & 2.80 & 2.74 & 2.72 & 2.68 \\
\hline
\end{tabular}

The features of the oil held in the gums are shown in Table IV. The acidity of that oil was about the same with the acidity of the degummed oil when the contact time was short, but it was smaller for longer contact time. The oil in the gums contained more unsaponifiable matter than the degummed oil and had an iodine value between the value of the degummed and of the crude oil.

Alkali neutralization is the most suitable method for the neutralization of water degummed or partially purified oils, because it contributes to the removal of the nonhydratable phosphatides (12) (13). In order to examine whether the alkali neutralization leads to a complete purification of the oil, a larger scale experiment was conducted. The condi- tions of hydration of $80^{\circ} \mathrm{C}$ with $2 \%(\mathrm{w} / \mathrm{w})$ water and $15 \mathrm{~min}$ contact time were selected. The alkali neutralization which followed the degumming, reduced the phosphorus content of the neutralized oil to 1-4 ppm depending on the conditions of neutralization (Table V), achieving an almost complete removal of phosphatides.

Table IV

Features of the oil in gums

\begin{tabular}{lllllllll}
\hline $\begin{array}{c}\text { Number of } \\
\text { experiment }\end{array}$ & 1 & 2 & 3 & 4 & 5 & 6 & 7 & 8 \\
\hline$\%$ & & &
\end{tabular}

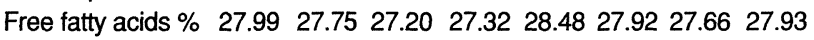
Unsaponifiable

$\begin{array}{lllllllll}\text { matter \% } & 4.60 & 4.58 & 4.31 & 4.32 & 4.55 & 4.31 & 4.29 & 4.22\end{array}$ lodine value $\quad$\begin{tabular}{llllllll}
78.57 & 78.79 & 79.71 & 79.88 & 78.47 & 78.72 & 79.69 & 79.90 \\
\hline
\end{tabular}

Table V

Phosphorus content of neutralized oils

\begin{tabular}{ccc}
\hline Neutralization & at $60^{\circ} \mathrm{C}$ with $10^{\circ} \mathrm{Be}$ & at $70^{\circ} \mathrm{C}$ with $20^{\circ} \mathrm{Be}$ \\
\hline ppm $\mathrm{P}$ of neutralized oils & 1 & 4 \\
\hline
\end{tabular}

\section{CONCLUSIONS}

The water degumming of high acidity solvent extracted olive oil did not result in complete removal of phosphatides. The greater removal of phosphatides (representing removal of phosphorus) obtained under the examined conditions was $48 \%$ of the principal phosphatide content of crude oil. The increase of the contact time of hydration contributed to a larger removal of phosphorus.

The method of phosphatides hydration was not suitable for the complete degumming of solvent extracted olive oil with high acidity. It was satisfying only for the partial purification of the oil removing $35-48 \%$ of the principal phosphorus content of crude oil. Complete removal of phosphatides was done during alkali neutralization.

\section{BIBLIOGRAPHY}

1. Braae, B. (1976).-«Degumming and refining practices in Europe»-J. Am. Oil.Chemists'Soc. 53, 353-357.

2. Bernardini, E. (1983).-«Vegetable oils and fats processing». Vol. II, p. 87-98.-Publishing House B.E. Oil, Rome.

3. Andersen, A. (1962).-«Refining of oils and fats for edible purposes».2nd Ed.-Pergamon Press, New York.

4. Ohlson, R. and Svensson, C. (1976).-«Comparison of oxalic acid and phosphoric acid as degumming agents for vegetable oils".-J. Am. Oil Chemists'Soc. 53, 8-11.

5. Diosady, L. (1982).-«Chemical degumming of canola oils».-J. Am. Oil Chemists'Soc. 59, 313-316.

6. Leibovitz, Z. and Ruckenstein, C. (1981).-«New processes in degumming, bleaching, deacidification-deodorization and winterizing of edible oils".-Rev. Fr. Corps Gras 28, 303-308.

7. Diosady, L. (1984).-«Scale-up of canola oil degumming».-J. Am. Oil Chemists'Soc. 61, 1366-1369.

8. Racicot, I. and Handel, A. (1983).-«Degumming of soybean oil: quantitative analysis of phospholipids in crude and degummed oil».-J. Am. Oil Chemists'Soc. 60, 1098-1101.

9. Segers, J. and Van de Sande, R. (1989).-«Degumming-Theory and 
practice» in «World conference Proceedings-Edible Fats and Oils Processing: Basic principles and modern practices» p. 88-93.-D. Erickson (Ed), American Oil Chemists' Society, Champaign, Illinois.

10. Cowan, J. (1976).-«Degumming, refining, bleaching, and deodorization theory".-J. Am. Oil Chemists'Soc. 53, 344-346.

11. Haralsson, G. (1983).-«Degumming, Dewaxing and Refining»--J. Am. Oil Chemists' Soc. 60, 203A-208A.

12. Carr, R. (1976).-«Degumming and refining practices in the U.S.».-J. Am. Oil Chemists' Soc. 53, 347-352.

13. Carr, R. (1978).-«Refining and degumming systems for edible fats and oils».-J. Am. Oil Chemists'Soc. 55, 765-771.

14. Wiedermann, L. (1981).-«Degumming, refining and bleaching-Soybean oil».-J. Am. Oil Chemists' Soc. (3) 159A.

15. François, R. (1974).-«Les industries des Corps Gras, Biochemie, Extraction, Raffinage, Nuisances and Réglementation»-Genéve.

16. Locks, L. and Van Rede, C. (1966).-«Laboratory Handbook for oil and fat analyst".-Academic Press, London.

17. Wolff, J.P. (1968).-«Manuel d' analyse des corps gras».-Azoulay Ed., París.

18. Official and Tentative Methods of the American Oil Chemists'Society (1964).-3rd Ed. (revised to 1977).-AOCS, Champaign, Illinois.

19. Formo, M.; Jungermann, E.; Norris, F. and Sonntag, N. (1979).-«Bailey's Industrial Oil and Fat Products». Vol. 1.-John Wiley \& Sons.

(Recibido: Febrero 1993) 